\title{
AKTIVITAS ANTIBAKTERI EKSTRAK DAUN MAYANA (Coleus atropurpureus [L] Benth) BERDASARKAN TINGKAT KEPOLARAN PELARUT
}

\section{[Antibacterial Activity of Mayana Plant Leaf Extract (Coleus atropurpureus [L] Benth) Using Several Levels of Solvent Polarity]}

\author{
Nur Madinah Rizal ${ }^{{ }^{\star}}$, Nurhaeni ${ }^{1}$, Ahmad Ridhay ${ }^{1}$ \\ 1) Jurusan Kimia, Fakultas MIPA, Universitas Tadulako \\ Jl. Soekarno Hatta, Kampus Bumi Tadulako Tondo Palu, Telp. 0451- 422611 \\ *)Corresponding Author: nurmadinah.rizal@yahoo.com
}

Diterima 8 Maret 2018, Disetujui 31 Juli 2018

\begin{abstract}
A study was conducted on the antibacterial activity test of leaf extract (Coleus atropurpureus $[L]$ Benth.) from several levels of solvent polarity. The purpose of this research was to find out the capacity inhibition of extract against Gram positive bacteria (Streptococcus mutans) and gram negative bacteria (Shigella dysenteriae) based on polarity level of solvent. The method of extraction used in this research was maceration at 4 levels of solvent polarity, starting from non polar solvent ( $n$ hexane), followed by semi polar solvent (ethyl acetate and chloroform) and polar solvent (ethanol). The antibacterial activity test was performed by diffusion well test, and the observed parameter was the inhibitory diameter. The results showed that $n$-hexane extract gave the highest inhibition in gram negative bacteria (Shigella dysenteriae) and Gram positive bacteria (Streptococcus mutans) were $22.81 \mathrm{~mm}$ and $20.99 \mathrm{~mm}$, respectively. In conclusion, mayana leaf extract can inhibit the growth of Shigella dysenteriae and Streptococcus mutans bacteria with very strong category.
\end{abstract}

Keywords : Mayana (Coleus atropurpureus [L] Benth), Solvent polarity, inhibition, Antibacterial

\begin{abstract}
ABSTRAK
Telah dilakukan penelitian tentang Uji aktivitas antibakteri ekstrak daun mayana (Coleus atropurpureus $[L]$ Benth.) dari beberapa tingkat kepolaran pelarut. Tujuan penelitian ini adalah mengetahui daya hambat ekstrak daun mayana terhadap bakteri gram positif (Streptococcus mutans) dan bakteri gram negatif (Shigella dysenteriae) berdasarkan tingkat kepolaran pelarut. Metode ekstraksi yang digunakan dalam penelitian ini yaitu metode maserasi dengan 4 tingkat polaritas pelarut yang dimulai dari pelarut non polar ( $n$-heksan), diikuti dengan pelarut semipolar (etil asetat dan kloroform) dan pelarut polar (etanol). Pengujian aktivitas antibakteri dilakukan dengan uji metode sumur difusi, dan parameter yang diamati adalah diameter daya hambat. Hasil penelitian menunjukan bahwa ekstrak $n$-heksan memberikan daya hambat tertinggi pada bakteri gram negatif (Shigella dysenteriae) dan ektrak $n$-heksan pada bakteri gram positif (Streptococcus mutans) berturut-turut adalah $22.81 \mathrm{~mm}$ dan $20.99 \mathrm{~mm}$. Jadi, ekstrak daun mayana dapat menghambat bakteri Shigella dysenteriae dan Streptococcus mutans dengan kategori yang sangat kuat.
\end{abstract}

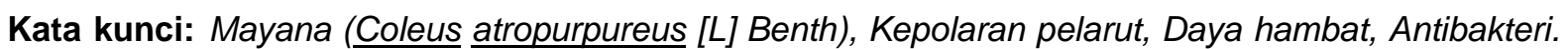




\section{LATAR BELAKANG}

Penggunaan bahan alam terutama dari tumbuhan sebagai obat tradisional telah dikenal luas oleh masyarakat Indonesia. Hal ini dapat dilihat dari banyaknya produk ramuan tradisional, baik yang diolah dengan tehnik sederhana maupun modern. Pemanfaatan tanaman yang dijadikan sebagai obat pada umumnya untuk mencegah berbagai macam penyakit, pemeliharaan maupun pemulihan kesehatan (Bellanti, 1993).

Daun mayana adalah daun pucuk Plectranthus scutellarioides (L.) Benth, sinonim Coleus scutellaroides (L.) Benth, suku Lamiaceae. Dilihat secara makroskopik berupa daun tunggal berwarna ungu kecoklatan sampai ungu kehitaman,setiap daerah mempunya nama yang berbeda untuk sebutan daun mayana ini, penggunaan secara empiris sebagai obat wasir, peluruh haid dan penambah nafsu makan. Penelitian terhadap aktivitas antibakteri dan peluruh dahak penderita TBC telah dilakukan terhadap ekstrak uji daun mayana dan menunjukkan hasil yang positif, begitu pula dengan uji metabolit sekunder menyatakan positif tanin katekat dan flavonoid yang banyak (Nugroho, 2003).

Golongan senyawa metabolit sekunder adalah alkaloid, flavonoid, sapponin, tanin, steroid dan triterpenoid (Harbone, 1987). Metabolit sekunder ada yang berperan sebagai antimikroba, antibiotik, antioksidan, antikanker, anti koagulan darah dan dapat menghambat efek karsinogenik (Copriady et al., 2005). Uji metabolit sekunder sebagai antibakteri selalu didahului dengan ekstraksi pelarut yang bertujuan untuk menarik metabolit sekunder yang bersifat antibakteri. Senyawa polar akan mudah terlarut dalam pelarut polar, sedangkan senyawa nonpolar melarut dalam pelarut non polar, dan senyawa semi polar melarut dalam pelarut semi polar juga.

Berdasarkan hasil penelitian yang dilakukan oleh Lisdawati (2008) menunjukkan bahwa sampel simplisia daun mayana mengandung golongan senyawa kimia terpenoid (termasuk minyak atsiri), tanin (dalam jumlah besar), tanin katekat dan flavonoid. Ekstrak etanol daun mayana (Coleus atropurpureus [L] Benth) memiliki aktivitas sebagai antibakteri terhadap S.aureus, E.coli dan P.aeruginosa dengan rata-rata diameter zona hambat pada konsentrasi $80 \%$ untuk S.aureus $26,33 \mathrm{~mm}$, untuk E.coli 29,17 $\mathrm{mm}$ dan untuk P.aeruginosa 31,83 mm (Mpila, 2012). Ekstrak n-heksan dari buah labu air (Lagenari skeraria) menghasilkan diameter zona hambat paling tinggi dibandingkan dengan ekstrak lain terhadap bakteri Bacillus cereus 14,3 mm dan Salmonella typhy 9,8 mm (Marliana, 2011).

Jenis pelarut yang biasa digunakan dalam proses ekstraksi sampel yaitu etanol, etil asetat, kloroform dan $n$-heksan. Pemilihan pelarut berdasarkan tingkat kepolaran yang berbeda bertujuan untuk memperoleh pelarut yang dapat 
mengekstrak zat aktif antibakteri dalam jumlah besar dan memiliki aktifitas tinggi. Penggunaan beberapa pelarut pada ekstraksi daun mayana sangat perlu dilakukan karena senyawa aktifnya yang memiliki aktivitas antibakteri belum diketahui sifat kepolarannya.

\section{METODE PENELITIAN}

\section{Bahan dan Peralatan}

Bahan dasar yang digunakan dalam penelitian ini adalah daun mayana diperoleh di daerah Petobo, Palu Selatan Sulawesi Tengah, Bahan lainnya berupa bakteri patogen Streptococcus mutans, Shigella dysenteriae, etanol, $n$-heksan,etil asetat, kloroform, reagen dragendroff, $\mathrm{FeCl}_{3}, \mathrm{H}_{2} \mathrm{SO}_{4}$ Pekat, $\mathrm{HCl}$ pekat, $\mathrm{CH}_{3} \mathrm{COOH}$ glasial, akuades, Nutrien Agar (NA), serbuk magnesium, aluminium foil, kertas saring whatman no.1, dan tissue.

Peralatan yang digunakan dalam penelitian ini adalah neraca analitik, blender, ayakan 60 mesh, oven, autoklaf, inkubator, laminar, rotary vakum evaporator, jangka sorong, botol semprot, spatula, sendok zat, Bunsen, pipet tetes, jarum ose dan alat-alat gelas yang umumnya digunakan dalam Laboratorium mikrobiologi dan Laboratorium kimia.

\section{Prosedur Penelitian}

Penelitian ini dilaksanakan dalam empat tahap yaitu tahap preparasi sampel, tahap ekstraksi, tahap uji golongan senyawa dan tahap uji aktivitas antibakteri daun mayana. Tahap ekstraksi daun mayana dengan metode maserasi bertingkat berdasarkan tingkat kepolaran pelarut, dan analisis aktivitas antibakteri dengan metode sumur difusi.

\section{Tahap pengolahan daun mayana}

Daun mayana dicuci bersih, diiris tipis-tipis dan dikering anginkan dan dihaluskan menggunakan blender dan diayak dengan ayakan 60 mesh untuk mendapatkan daun mayana dalam bentuk tepung, kemudian tepung daun mayana disimpan untuk digunakan pada prosedur selanjutnya.

\section{Ekstraksi daun mayana}

Ekstraksi dilakukan menggunakan metode maserasi dengan menggunakan tiga jenis pelarut. Ekstraksi pertama digunakan pelarut non polar yakni $n$ heksan dengan cara menimbang tepung daun mayana sebanyak 100 gram, kemudian dimasukkan ke dalam erlenmeyer $1000 \mathrm{~mL}$. Selanjutnya ditambahkan $500 \mathrm{~mL} n$-heksan. Campuran diaduk selama 10 menit setelah itu disimpan selama $3 \times 24$ jam, kemudian disaring secara vakum. Residu yang diperoleh dikering anginkan, selanjutnya dimasukkan ke dalam erlenmeyer 1000 $\mathrm{mL}$ dan ditambakan pelarut kloroform sebanyak $500 \mathrm{~mL}$. Campuran selanjutnya di aduk selama 10 menit setelah itu di simpan selama $3 \times 24$ jam kemudian disaring lagi secara vakum. Residu yang dihasilakn dikering anginkan, kemudian dimasukkan ke dalam erlenmeyer 1000 $\mathrm{mL}$ dan etil asetat sebanyak $500 \mathrm{~mL}$. 
Campuran selanjutnya diaduk selama 10 menit setelah it disimpan selama $3 \times 24$ jam kemudian disaring lagi secara vakum. Residu yang dihasilkan dikering anginkan, kemudian dimasukkan ke dalam erlenmeyer $1000 \mathrm{~mL}$ dan ditambahkan etanol sebanyak $500 \mathrm{~mL}$. Campuran diaduk selama $3 \times 24$ jam, kemudian disaring lagi secara vakum, selanjutnya dievaporator dan hasilnya disimpan untuk uji fitokimia dan antibakteri.

\section{Uji fitokimia secara kualitatif}

Uji fitokimia dilakukan untuk mengetahui kandungan metabolit sekunder pada ekstrak etanol, $n$-heksan, etil asetat dan kloroform daun mayana seperti tannin, flavonoid, alkaloid, polifenol dan steroid dengan menggunakan pereaksi yang spesifik, meliputi :

\section{a. Uji tanin dan polifenol (Harborne, 1987)}

Sebanyak $1 \mathrm{~mL}$ ekstrak di masukkan ke dalam tabung reaksi, kemudian ditambahkan 3 tetes larutan $\mathrm{FeCl}_{3} 5 \%$. Uji positif ditunjukkan dengan terbentuknya warna hijau hingga hitam.

\section{b. Uji flavonoid (Harborne, 1987)}

Sebanyak $1 \mathrm{ml}$ ekstrak ditambahkan 0,5 gram serbuk magnesium dan 10 tetes $\mathrm{HCl}$ pekat (pereaksi shinoda), bila bereaksi positif akan menghasilkan larutan berwarna jingga, merah muda atau merah

\section{c. Uji alkaloid (Harborne, 1987)}

Sebanyak $1 \mathrm{~mL}$ ekstrak di masukkan ke dalam tabung reaksi, kemudian ditambahkan 3 tetes pereaksi dragendorff.
Uji positif ditunjukkan dengan adanya endapan jingga.

\section{d. Uji steroid (Harborne, 1987)}

Sebanyak $1 \mathrm{~mL}$ ekstrak di masukkan ke dalam tabung reaksi, ditambahkan 10 tetes $\mathrm{CH}_{3} \mathrm{COOH}$ anhidrat dan 2 tetes $\mathrm{H}_{2} \mathrm{SO}_{4}$ pekat kemudian dikocok beberapa menit. Uji positif ditunjukkan terbentuknya warna biru atau hijau.

\section{Pengujian aktivitas antibakteri dengan metode sumur difusi (Darmawati, 2009)}

Pada pengujian zona hambat bakteri digunakan metode sumur difusi. Media Nutrien Agar (NA) sebanyak $25 \mathrm{ml}$ dicampur dengan $25 \mu \mathrm{L}$ suspensi bakteri uji sesuai perlakuan (Shigella dysenteriae dan Streptococcus mutans, dihomogenkan lalu dituang dalam cawan petri steril dan dibiarkan sampai memadat. Setelah itu dibuat sumur yang berdiameter $\pm 9 \mathrm{~mm}$ menggunakan alat pelubang. Memakai 4 cawan untuk semua ekstrak, Cawan pertama berisi 3 lubang atau sumur (lubang pertama untuk ekstrak $n$-heksan, lubang kedua untuk kontrol positif berupa Kloramfenikol $0,1 \%$ dan lubang ketiga untuk kontrol negatif berupa pelarut $n$ heksan). Untuk cawan ke 2 sampai ke 4 dilakukan perlakuan yang sama tetapi memakai ekstrak dan pelarut yang berbeda (ekstrak kloroform, etil asetat dan etanol), kemudian diinkubasi selama 24 jam pada suhu $37^{\circ} \mathrm{C}$, selanjutnya diamati dan diukur diameter zona hambat dengan jangka sorong. 
HASIL DAN PEMBAHASAN

\section{Metabolit sekunder dalam ekstrak daun mayana}

Hasil skrining fitokimia pada daun mayana dari empat jenis pelarut, disajikan pada Tabel 1.

Tabel 1. Hasil analisis golongan senyawa ekstrak daun mayana dari keempat jenis pelarut.

\begin{tabular}{lcccc}
\hline \multirow{2}{*}{$\begin{array}{l}\text { Golongan } \\
\text { Senyawa }\end{array}$} & \multicolumn{4}{c}{ Jenis Ekstrak dengan pelarut } \\
\cline { 2 - 5 } & $\begin{array}{c}n- \\
\text { heksan }\end{array}$ & Kloroform & $\begin{array}{c}\text { Etil } \\
\text { Asetat }\end{array}$ & Etanol \\
\hline Flavonoid & - & - & - & ++ \\
Alkaloid & +++ & - & + & + \\
$\begin{array}{l}\text { Steroid } \\
\text { Fenol }\end{array}$ & ++ & + & - & - \\
dan & - & + & + & ++ \\
tannin & & & & \\
\hline
\end{tabular}

Pada Tabel 1 terlihat bahwa ekstrak n-heksan terdeteksi adanya steroid dan alkaloid, tetapi tidak terdeteksi adanya flavonoid dan tannin. Hal tersebut menunjukan bahwa dalam daun mayana terdapat senyawa steroid dan alkaloid yang bersifat nonpolar. Ini sesuai dengan pendapat Lestiani dan Lanny (2008), tingkat kepolaran pelarut menentukan jenis dan jumlah senyawa yang dapat diekstrak dari bahan. Pelarut akan mengekstrak senyawa-senyawa yang mempunyai kepolaran yang sama dengan kepolaran pelarut yang digunakan.

Pada ekstrak kloroform terdeteksi adanya steroid dan tanin dalam jumlah sedikit, sedangkan untuk ekstrak etil asetat terdeteksi adanya alkaloid dan tanin. Kedua senyawa ini terdeteksi juga dalam ekstrak etanol, yang berarti alkaloid dan tanin yang ada pada daun mayana terdiri atas alkaloid dan tanin semi polar serta alkaloid dan tanin polar. Fakta-fakta ini sesuai dengan apa yang dilaporkan oleh Simaremare (2014) bahwa senyawa golongan alkaloid bersifat semipolar yang dapat larut dalam pelarut semi polar karena mengandung nitrogen sebagai bagian dari sistem sikliknya serta mengandung substituen yang bervariasi seperti gugus amina, amida, fenol dan metoksi.

Pada Table 1 juga memperlihatkan senyawa flavonoid banyak terdeteksi dalam ekstrak etanol, tetapi tidak terdeteksi dalam ketiga ekstrak yang lain yaitu pada etil asetat, kloroform maupun ekstrak $n$-heksan, yang menunjukan flavonoid yang ada dalam daun mayana adalah flavonoid yang bersifat polar. Senyawa golongan flavonoid memiliki ikatan dengan gugus gula menyebabkan flovonoid bersifat polar (Shimaremare 2014).

\section{Aktivitas Antibakteri dan Daya Hambat Ekstrak Daun Mayana}

Berdasarkan hasil penelitian dari 2 bakteri masing-masing 3 kali pengulangan diperoleh perbedaan zona hambat dari masing-masing ekstrak $n$-heksan, kloroform, etil asetat dáı etanol. Uji aktivitas ekstrak daun mayana terhadap pertumbuhan bakteri gram positif (Streptococcus mutans) dan gram negatif (Shigella dysenteriae) dengan menggunakan metode sumur difusi, yang di tandai dengan terbentuknya zona bening di sekitar sumuran. Antibiotik 
Chloramphenicol sebagai kontrol positif dan kontrol negatif berupa 4 pelarut yaitu $n$-heksan, kloroform, etil asetat dan etanol. Pengamatan terhadap diameter zona hambat dari masing-masing ekstrak dengan pengukuran menggunakan jangka sorong otomatis. Hasil pengukuran zona hambat bakteri disajikan pada gambar 1,2 dan Tabel 2.

Tabel 2 Hasil zona hambat bakteri gram negative Shigella dysenteriae dan bakteri gram positif Streptococcus mutans.

\begin{tabular}{lcc}
\hline & \multicolumn{2}{c}{ Diameter Rata-rata Zona Hambat (mm) } \\
\cline { 2 - 3 } & Shigella dysenteriae & Streptococcus mutans \\
\hline Ekstrak n-heksan & 22,81 & 20,99 \\
Ekstrak Kloroform & 18,19 & 18,08 \\
Ekstrak Etil asetat & 18,01 & 17,56 \\
Ekstrak Etanol & 18,40 & 20,52 \\
\hline \multicolumn{1}{c}{ Kontrol positif chloramphenicol } \\
\hline Kontrol Positif & 37,07 & 32,6 \\
& 36,93 & 32,58 \\
& 34,94 & 31,72 \\
& 37,03 & 31,91 \\
\hline Pelarut $n$-Heksan & Kontrol negatif pelarut \\
Pelarut Kloroform & 0 & 0 \\
Pelarut Etil asetat & 0 & 0 \\
Pelarut Etanol & 0 & 0 \\
\hline
\end{tabular}
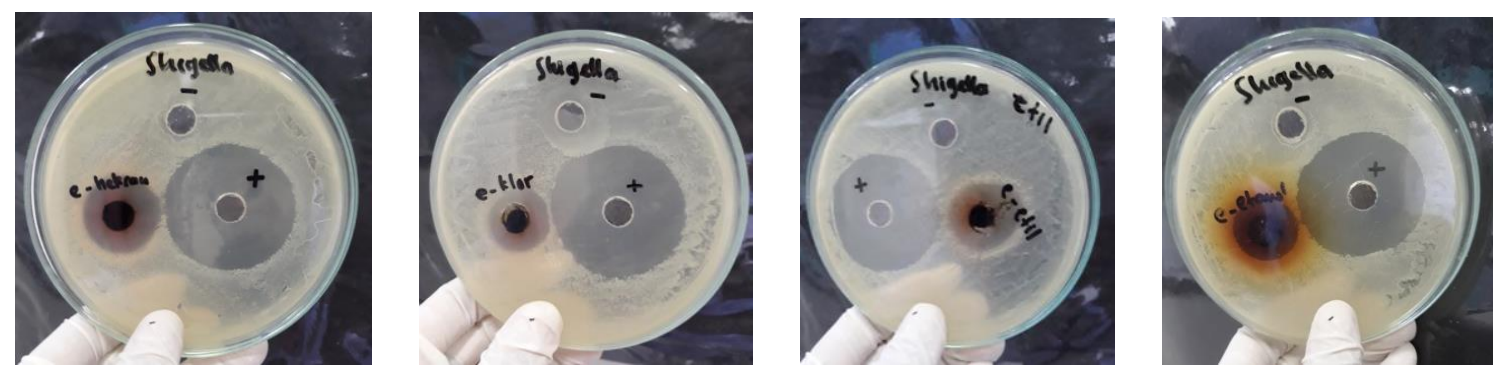

Gambar 1 Hasil uji aktivitas antibakteri ekstrak n-heksan, kloroform, etil asetat dan etanol terhadap bakteri gram negatif (Shigella dysenteriae)
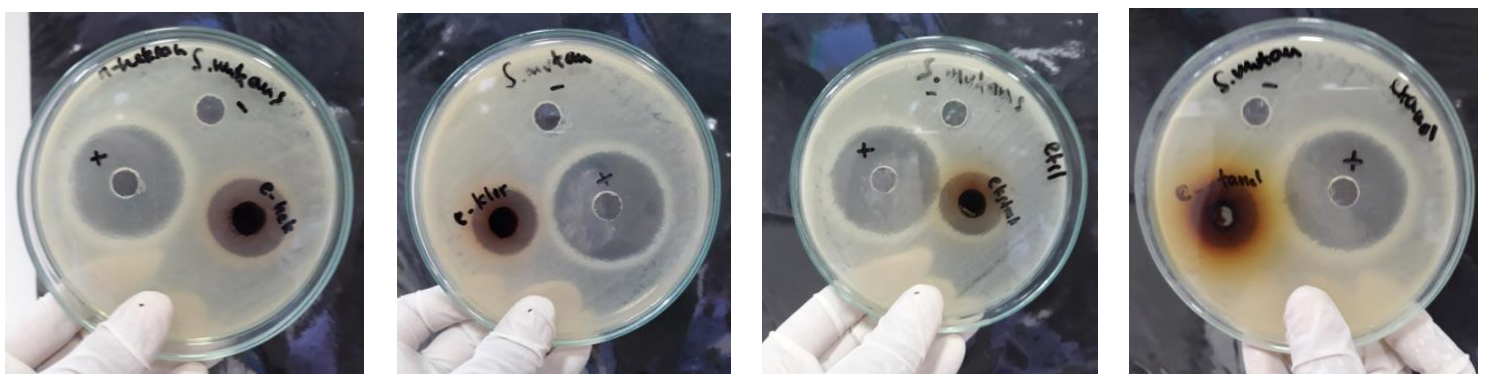

Gambar 2 Hasil uji aktivitas antibakteri ekstrak n-heksan, kloroform, etil asetat dan etanol terhadap bakteri gram positif (Streptococcus mutans)

Pada Tabel 2 menunjukan ekstrak $n$-heksan memberikan daya hambat terhadap semua bakteri uji. Diameter zona hambat tertinggi $(22,81 \mathrm{~mm})$ terdapat 
pada bakteri Shigella dysenteriae. Dengan demikian Steroid dan Alkaloid non polar dalam daun mayana bersifat antibakteri. Kandungan ekstrak $n$-heksan berupa senyawa alkaloid yaitu golongan senyawa basa nitrogen yang sebagian besar berupa heterosiklik dan banyak terdapat pada tanaman, mekanisme penghambatan pertumbuhan bakteri oleh senyawa alkaloid yaitu dengan cara menggunakan komponen penyusun peptidoglikan pada sel bakteri, sehingga lapisan dinding sel tidak terbentuk secara utuh dan menyebabkan kematian sel tersebut (Robinson, 1995).

Menurut Ernawati (2007), senyawa yang diduga dapat ditarik oleh pelarut non polar misalnya $n$-heksan adalah asetogenin, dan berbagai macam terpen seperti myrcene, thymol. Beberapa hasil penelitian menunjukkan bahwa senyawa terpenoid yang memiliki aktivitas antimikroba, yaitu monoterpenoid linalool, diterpenoid(-)hardwicklic acid, phytol, triterpenoid saponin dan triterpenoid glikosida (Gunawan, 2008). Thanh (2006) telah mengisolasi senyawa triterpen glikosida dari teripang pasir dan memiliki aktivtas antijamur, antibakteri, dan sitotoksik. Berdasarkan hasil penelitian Heni (2015) fraksi n-heksana mengandung senyawa triterpenoid, tanin, saponin, flavonoid, dan terpenoid yang dapat menghambat pertumbuhan bakteri, dengan berbagai mekanisme kerja.

Ekstrak kloroform dan etil asetat yang mengandung alkaloid semi polar, steroid semi polar dan tannin semi polar memberikan zona hambar terhadap semua bakteri uji, meskipun diameter zona hambatnya berbeda-beda. Parekh et al., (2005) menyatakan bahwa kepolaran senyawa hasil ekstraksi oleh setiap pelarut mempengaruhi aktivitas antibakteri dengan kemampuan zat tersebut untuk menyebar pada media yang digunakan dalam pengujian aktivitas antibakteri. Tanin pada tanaman digunakan sebagai proteksi dari mikroorganisme yang mensekresikan enzim yang dapat membuat dinding sel tanaman lisis, enzim ini akan inaktif ketika tanin yang ada pada tanaman terikat dengan enzim yang disekresikan oleh mikroorganisme patogen tersebut (Heldt dan Hans, 2004).

Menurut Gunawan et al., (2008), senyawa terpenoid mempunyai kemampuan dalam menghambat bakteri. Mekanisme kerja antibakteri yaitu dengan cara bereaksi dengan porin membran luar dinding sel bakteri dan selanjutnya akan membentuk ikatan kuat sehingga porin menjadi rusak. Porin yang telah rusak berakibat pada masuknya senyawa kemudian akan mengurangi permeabilitas dinding sel bakteri. Berkurangnya permeabilitas dinding sel bakteri akan menyebabkan bakteri kekurangan nutrisi dan pertumbuhan bakteri terhambat hingga mati (Cowan, 1999).

Ekstrak etanol mengandung senyawa-senyawa polar (flavonoid, alkaloid dan tanin) juga memberikan zona hambat terhadap semua bakteri uji. Zona 
hambat tertinggi $(20,52 \mathrm{~mm})$ ditemukan pada Streptococcus mutans dan zona hambat terendah $(18,4)$ ditemukan pada Shigella dysenteriae. Ekstrak etanol tersusun atas senyawa flavonoid atau kelompok senyawa fenol yang dapat mengikat protein, sehingga menganggu proses metabolisme bakteri (Ganiswara, 1995). Sabir (2005) mealporkan bahwa gugus - $\mathrm{OH}$ pada senyawa flavonoid akan mengakibatkan timbulnya efek toksik terhadap bakteri, sedangkan pada ekstrak tanin terdiri dari campuran senyawa polifenol kompleks dan umumnya tergabung dengan karbohidrat sederhana, seperti glukosa (Linggawati dkk, 2002). Tanin sebagai antibakteri bekerja dengan cara mengganggu sintesis peptidoglikan pada proses pembentukan dinding sel bakteri. Etanol absolut memiliki efek bakterisidal yang lebih lemah dibandingkan campuran antara alkohol dan air. $100 \%$ etanol mengkoagulasi protein pada dinding sel, sehingga terjadi pengerasan protein pada dinding sel.

Parekh et al. (2005) melaporkan bahwa aktivitas antibakteri sangat dipengaruhi oleh tingkat kepolaran senyawa. Menurut Schlegel (1993), bahwa setiap senyawa dengan kepolaran yang berbeda dapat memberikan efek yang berbeda dalam menghambat pertumbuhan bakteri. Perbedaan aktivitas dikarenakan senyawa metabolit sekunder memiliki efek sinergis yang berbeda tergantung dari sifat dan morfologi dari bakteri tersebut. Faktor lain yang menyebabkan perbedaan diameter zona hambat dari ekstrak tersebut adalah perbedaan senyawa aktif yang terdapat pada ekstak. Hal ini sesuai dengan pendapat Prescott (2005), bahwa ukuran dari zona hambat dipengaruhi oleh beberapa hal, seperti tingkat sensitifitas dari organisme uji, kecepatan difusi dari senyawa antibakteri dan konsentrasi senyawa antibakteri.

Tingkat kekuatan antibakteri terbagi menjadi 4 berdasarkan zona hamat yang terbentuk, yaitu sangat kuat bila zona hambat $>20 \mathrm{~mm}$, kuat $10-20 \mathrm{~mm}$, sedang 5-10 $\mathrm{mm}$ dan lemah $<5 \mathrm{~mm}$ (Davis dan Stout, 1971 dalam Arista, 2013). Senyawa antibakteri dalam ekstrak $n$-heksan daun mayana termasuk antibakteri daya hambat sangat kuat terhadap kedua bakteri uji, senyawa antibakteri dalam ekstrak etil asetat termasuk antibakteri daya hambat kuat terhadap kedua bakteri uji, dan senyawa antibakteri dalam ekstrak kloroform dan etanol termasuk antibakteri daya hambat kuat terhadap bakteri shigella dysenteriae. Sedangkan pada bakteri Streptococcus mutans etanol termasuk antibakteri daya hambat sangat kuat dan kloroform termasuk antibakteri daya hambat kuat.

\section{KESIMPULAN}

Berdasarkan hasil penelitian yang telah dilakukan dapat disimpulkan bahwa daun mayana mengandung senyawa antibakteri yang bersifat non polar yaitu alkaloid dan steroid. Senyawa semi polar 
yaitu alkaloid, steroid Fenol dan tanin serta senyawa polar yaitu flavonoid, alkaloid, Fenol dan tannin.

Zona hambat tertinggi ekstrak daun mayana terhadap bakteri gram positif diperoleh dari ekstrak $n$-heksan 20,99 mm pada bakteri Streptococcus mutans dan termasuk ke dalam daya hambat sangat kuat. Sedangkan pada bakteri gram negatif diperoleh dari ekstrak $n$-heksan 22,81 $\mathrm{mm}$ pada bakteri Shigella dysenteriae dan termasuk ke dalam daya hambat sangat kuat.

\section{DAFTAR PUSTAKA}

Arista, Y. N. 2013. Formulasi dan Uji Aktivitas Gel Antijerawat Ekstrak Umbi Bakung (Crinum Asiaticum L.) Terhadap Bakteri Staphylococcus aureus secara in Vitro. (http://ejournal.unstrat.ac.id/indeks.p hp/pharmacon/article/view/1552).

Diaskes 1 November 2016.

Bellanti, J.A. 1993. Imunologi III, diterjemahkan oleh Samik Wahab, 203-211, Yogyakarta: Gadjah Mada University Press.

Copriady. J., Yasmi E., dan Hidayati. 2005. Isolasi dan karakterisasi senyawa kumarin dari kulit buah jeruk purut (Citrus hystrix DC). Jurnal Biogenesis Vol. 2(1):13-15.

Cowan, M.M. 1999. Plant Products as Antimicrobial Agents. Clinical Microbiology Reviews. 12(4) : 56482.

Darmawati, S. 2009. Keanekaragaman genetik Salmonella typhi. Jurnal Kesehatan. 2 (1): 28-32.

Davis dan Stout. 1971. Disc plate method of microbiological antibiotic essay. Jounal Of Microbiology. 22 (4).

Mpila D. A., Fatimawali. 2012. Uji Aktivitas Antibakteri Ekstrak Etanol Daun Mayana (Coleus atropurpureus [L] Benth) Terhadap Staphylococcus aureus, Escherichia coli dan Pseudomonas aeruginosa Secara In-Vitro. Pharmacon. 1(1).

Ernawati. 2007. Penapisan dan Fraksinasi Senyawa Antibakteri dari Rumput Laut Bulu Ayam. [Skripsi]. Bogor: Institut Pertanian Bogor.

Marliana E. 2011. Uji Fitokimia dan Aktivitas Antibakteri ekstrak Kasar Etanol, n-heksan,etil asetat dan metanol dari Buah Labu Air (Lagenari skeraria). Jurnal Kimia Mulawarman. 8(2).

Ganiswara, S.G. 1995. Farmakologi dan terapi edisi ke-4. Jakarta: FKUI.

Gunawan, S.G. 2008. Farmakologi dan Terapi Edisi ke-5. Jakarta: FKUI

Harborne, J.B 1987. Metode fitokimia, edisi ke-2. ITB. Bandung.

Heldt dan Hans. 2004. Plant Biochemistry. New York. Elsevier Academic Press.

Lestiani dan lanny. 2008. Vitamin Larut Air. Jakarta: Universitas Indonesia.

Linggawati, A., Muhadariana, Erman, Azman dan Midiarty. 2002. Pemanfaatan tanin limbah kayu industri kayu lapis untuk modifikasi resin fenol formaldehid. Diuggah di https://www.researchgate.net/publi cation/242613317_PEMANFAATA N_TANIN_LIMBAH_KAYU_INDUS TRI_KAYU_LAPIS_UNTUK_MODI FIKASI_RESIN_FENOL_FORMAL DEHID, pada tanggal 4 September 2017.

Lisdawati. 2008. Karakterisasi daun mayana

(Pectranthus 
scutellariodes (L.) Bth.) dan buah sirih (Piper betle L.) secara fisiko kimia dari ramuan lokal antimalaria daerah Sulawesi Utara. Artikel Media Litbang Kesehatan Volume XVIII Nomor 4.

Nugroho Y A. 2003. Karakterisasi, uji toksisitas akut oral dan uji mukolitik tanaman mayana (Plectranthus scutellarioides (L) R. Br.). Laporan Penelitian. Jakarta : Penelitian dan Pengembangan Kesehatan 2003: hal. 5.

Parekh, J., Nair, R., Chanda, S. 2005. Preliminary screening of some folklore medicinal plants from western India for potential antimicrobial activity. Indian $J$. Pharmacol., 37: 408-409.

Prescott, LM. 2005. Microbiology. New York: Mc.Grow-Hill.

Robinson, T. 1995. Kandungan organik tumbuhan tinggi, edisi ke-4, Terjemahan Kosasih Padmawinata. Bandung: ITB Press.

Sabir, A. 2005. Aktivitas antibakteri flavonoid propolis trigono $\mathrm{sp}$ terhadap bakteri Streptococcus mutans (in vitro). Majalah kedoteran Gigi, 38 (3), 135-141.

Schlegel, G. Hans. 1993. General Microbiologi. Seventh Edition. England: Cambridge University Press.

Shimaremare, E. S. 2014. Skrining fitokimia Ekstrak Etanol Daun Gatal (Laporteae decumana (Roxb) Wedd). Pharmacy. 11 (1):98-107. 